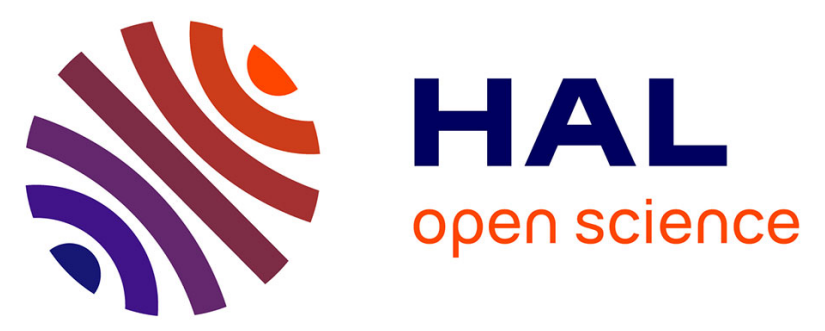

\title{
pH-modulated ion transport and amplified redox response of Keggin-type polyoxometalates through vertically-oriented mesoporous silica nanochannels
}

Neus Vilà, Pedro de Oliveira, Alain Walcarius, Israël Mbomekallé

\section{- To cite this version:}

Neus Vilà, Pedro de Oliveira, Alain Walcarius, Israël Mbomekallé. pH-modulated ion transport and amplified redox response of Keggin-type polyoxometalates through vertically-oriented mesoporous silica nanochannels. Electrochimica Acta, 2019, 309, pp.209-218. 10.1016/j.electacta.2019.03.119 . hal-02149606

\section{HAL Id: hal-02149606 \\ https://hal.univ-lorraine.fr/hal-02149606}

Submitted on 26 Nov 2020

HAL is a multi-disciplinary open access archive for the deposit and dissemination of scientific research documents, whether they are published or not. The documents may come from teaching and research institutions in France or abroad, or from public or private research centers.
L'archive ouverte pluridisciplinaire HAL, est destinée au dépôt et à la diffusion de documents scientifiques de niveau recherche, publiés ou non, émanant des établissements d'enseignement et de recherche français ou étrangers, des laboratoires publics ou privés. 


\title{
pH-modulated ion transport and amplified redox
}

\section{response of Keggin-type polyoxometalates through}

\section{vertically-oriented mesoporous silica nanochannels}

\author{
Neus Vilà, ${ }^{a * \xi}$ Pedro de Oliveira, ${ }^{b}$ Alain Walcarius ${ }^{a *}$ and Israël M. Mbomekallé, ${ }^{b *, \xi}$
}

a Laboratoire de Chimie Physique et Microbiologie pour les Matériaux et l'Environnement (LCPME), UMR 7564, CNRS-Université de Lorraine, 405 rue de Vandoeuvre, 54600 Villers-lesNancy, France

b Equipe d'Electrochimie et Photo-électrochimie, Laboratoire de Chimie Physique, Université Paris-Sud, UMR 8000, CNRS-Université Paris Saclay, Orsay F-91405, France

$\S$ These authors have contributed equally to this work

ABSTRACT. Cyclic voltammetry has been applied to characterize mass transport of a Keggintype polyoxometalates $\left(\left[\mathrm{SiW}_{12} \mathrm{O}_{40}\right]^{4-}\right)$ through vertically-aligned mesoporous silica thin films in aqueous media. The results indicate a drastic influence of $\mathrm{pH}$ and the ionic strength which may be rationalized in terms of electrostatic interactions and confinement effects. Diffusion of such bulky anionic electroactive species is considerably restricted at $\mathrm{pH}$ values higher than the point of zero charge of the silica for which the walls of the nanochannels are negatively charged. On the other hand, the positive charge density generated in more acidic solutions favors the ingress of $\left[\mathrm{SiW}_{12} \mathrm{O}_{40}\right]^{4-}$ species through the mesochannels, enhancing considerably the electrochemical response, except at high ionic strength due to competition for the binding sites. The accumulation 
of POM anions into the silica films can be even promoted by functionalization of the silica surface with propylammonium groups. In summary, $\mathrm{pH}$ tuning induced gating of the ionic flux through the silica nanopores, which can be somewhat modulated by the ionic strength by varying the thickness of the electrical double layer generated at the silica walls surface.

\section{INTRODUCTION}

Silica $\left(\mathrm{SiO}_{2}\right)$ is one of the most abundant amphoteric oxide materials and the speciation of surface hydroxyl groups ( because it carries either positive, negative or zero net charge depending on the $\mathrm{pH}$ of the surrounding solution and its ionic concentration. ${ }^{1}$ Depending upon different manufacturing processes, the point of zero charge for silica ranges from 2 to $3.5^{2,3}$ At $\mathrm{pH}$ below the point of zero charge, defined as the $\mathrm{pH}$ at which the positive and negative charges of a zwitterionic surface are balanced, protons can adsorb from solution to the oxide surface and generate protonated sites $\left(\equiv \mathrm{SiOH}_{2}{ }^{+}\right)$that result in an overall net positive charge at the interface. At $\mathrm{pH}$ values above the point of zero charge, protons desorb from hydroxyl groups into solution to create deprotonated sites $\left(\equiv \mathrm{SiO}^{-}\right)$and an overall negative surface charge. Across the entire $\mathrm{pH}$ range, the charged surface groups of the oxide material remain in equilibrium with neutral sites.

2D hexagonal silica-based mesostructures with pores uniformly packed in an orthogonal orientation to the underlying support can be prepared by means of an electro-assisted self-assembly (EASA) ${ }^{4}$ method. They represent an attractive model to evidence transport features at the mesoscale and constitute an ideal configuration ensuring good accessibility towards the electrode surface. The EASA method can afford vertically-oriented silica-based thin films with small pore size varying from 2 to $3 \mathrm{~nm}$ that can be slightly modulated as a result of the choice of the cationic 
surfactant employed either cetyltrimethylammonium bromide (CTAB) or octadecyltrimethylammonium bromide (OTAB) as template respectively. ${ }^{5}$ Functionalization of such vertically-oriented films can be basically achieved by three different methods: post-synthesis grafting (yet leading often to pore blocking effects), co-condensation processes essentially based on the use of an alkoxysilane and organosilanes (which is however limited to the use of simple organic functions ${ }^{6,7}$ ) and via more versatile click chemistry approaches (likely to generate a wide range of organic-inorganic hybrid films). ${ }^{8,9}$

Recent advances in nanofabrication techniques ${ }^{10,11,12}$ and growing interest in sensing particular molecules by nanofluidic devices $3,13,14,15$ have stimulated the research in the field of controlled ion transport through synthetic nanochannels. Nanochannels with charged surfaces having pore dimensions within the Debye length range are known to display selective transport properties which depend on the surface charge. ${ }^{16,17}$ When a charged surface is immersed into an electrolyte solution, ions of opposite charge are attracted to it, thereby forming an electrical double layer (EDL). The thickness of this double layer is dictated by the Debye length of the solution, which characterizes the length scale of the electrostatic screening between the charged species due to the finite concentration in the solution. Ion transport in nanoscale channels is thus expected to be strongly influenced by the effective partial charge inside channels of so small diameter, which can alter transport properties of electrolytes in confined geometries. ${ }^{18,19,20}$ Electrochemical techniques are good tools to study the mass transport of electroactive species through mesoporous silica films exhibiting such nanochannels. ${ }^{21}$ The diffusion of such redox probes is strongly dependent on the mesostructure type $\mathrm{e}^{22,23}$ and pore orientation. ${ }^{3}$ To date, however, the investigations made on vertically-oriented mesoporous silica nanochannels have been restricted to the diffusion of small 
molecules/ions or to evidencing size exclusion features (molecular sieving). ${ }^{5}$ Here we wish to extend it to bulkier species such as Keggin-type polyoxometalates.

PolyOxoMetalates (POMs) constitute a family of discrete chemical entities which are often considered as analogous to soluble molecular oxides. They form upon the polycondensation of similar or different oxometalate ions. The number of metallic centres associated in a single structure may vary from a few units up to several hundreds. The most convenient chemical elements for the reactions of formation of POMs are tungsten, molybdenum and vanadium, which will be found in their highest oxidation states $(+\mathrm{VI}$ or $+\mathrm{V}) \cdot{ }^{24,25,26}$ POMs exhibit an enormous potential in the sense that their composition can be specially tailored according to particular multistep and stereospecific syntheses. The latter allow to specifically incorporate in the scaffold different metallic cations, organic compounds or organometallic complexes. ${ }^{27,28,29}$ POMs may also be grafted on nano-structured materials such as graphene, ${ }^{30}$ carbon nanotubes, mesoporous silica and metal nanoparticles..$^{31,32,33,34,35}$ This grafting may rely on the formation of chemical bonds or be just a simple physisorption phenomenon. Among the great diversity of POMs described in the literature, we are interested in the Keggin-type structure, ${ }^{36}$ which seems to be the most known of all by far. We have chosen the $\left[\mathrm{SiW}_{12} \mathrm{O}_{40}\right]^{4-}$ polyoxoanion, which results from the condensation of twelve $\left\{\mathrm{WO}_{6}\right\}$ octahedra around a $\left\{\mathrm{SiO}_{4}\right\}$ tetrahedron (Figure 1A), as a good model for the present study as its electrochemical behaviour, both in solution and in the solid state, is known from previous reports. ${ }^{37,38,39}$

In this paper, we have carefully studied the effect of selected experimental parameters (i.e., $\mathrm{pH}$ of the surrounding solution and ionic strength) on the permeability properties of vertically-aligned mesoporous silica thin films (see top and cross-section TEM views on Figure 1B\&C) by using an anionic redox probe from Keggin-type POMs family, $\left[\mathrm{SiW}_{12} \mathrm{O}_{40}\right]^{4-}$. Compared to smaller redox 
probes (e.g., $\left.\mathrm{Fe}(\mathrm{CN}) 6^{3-4-}\right),{ }^{40}$ more restricted mass transport through the mesochannels might be expected. In addition, tuning the transport of ionic species through silica nanochannels by varying the ionic strength and $\mathrm{pH}$ of the solution has been underexplored. These two experimental parameters are of importance as $\mathrm{pH}$ will affect the surface charge density of silica and consequently the electrostatic interactions with the anionic species, $\left[\mathrm{SiW}_{12} \mathrm{O}_{40}\right]^{4-}$, and the ionic strength will define the EDL thickness likely to influence the transport of charged species through the small channels. Studying the optimal conditions favoring the mass transport of polyoxometalates trough the nanochannels is a prerequisite to succeed in their confinement inside these silica matrices, with possible applications in the field of (electro)catalysis or molecular electronics for instance.
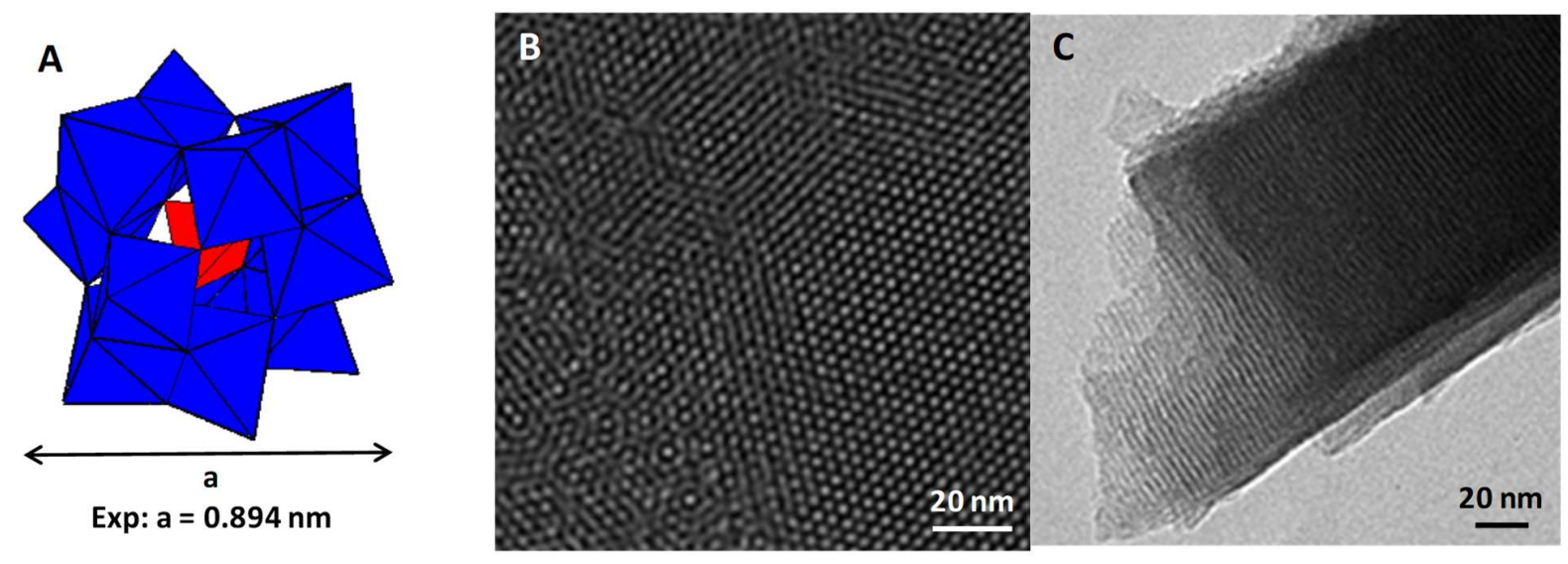

Figure 1. A) Representative structure of the heteropolyanion studied: $\left[\mathrm{SiW}_{12} \mathrm{O}_{40}\right]^{4-}$. B, C) Transmission electron micrographs of the vertically-oriented silica thin films: top-view (B) and cross-section (C).

\section{EXPERIMENTAL}

\subsection{Chemicals and reagents}


Tetraethoxysilane (TEOS, 98\%, Alfa Aesar), (3-aminopropyl)triethoxysilane (APTES, 99\%, Aldrich), ethanol (95-96\%, Merck), $\mathrm{NaNO}_{3}$ (98\%, Prolabo), $\mathrm{HCl}$ (37\% Riedel de Haen), cetyltrimethylammonium bromide (CTAB, 99\%, Acros), have been used as received. Pure samples of $\mathrm{K}_{4}\left[\mathrm{SiW}_{12} \mathrm{O}_{40}\right] .17 \mathrm{H}_{2} \mathrm{O}$ were obtained by following a synthetic procedure previously reported. ${ }^{41}$ They were dissolved at the desired concentration in aqueous solutions containing $\mathrm{H}_{2} \mathrm{SO}_{4}$ and/or $\mathrm{Na}_{2} \mathrm{SO}_{4}$ as supporting electrolyte.

\subsection{Preparation and functionalization of vertically-aligned mesoporous silica thin films}

The vertically-oriented silica thin films have been electrochemically generated on indium-tin oxide (ITO) electrodes according to the previously reported EASA procedure. ${ }^{5,42}$ A hydroalcoholic solution (10 $\mathrm{mL} \mathrm{H}_{2} 0 / 10 \mathrm{~mL}$ ethanol) containing $100 \mathrm{mM}$ of the silica precursor (TEOS), $32 \mathrm{mM}$ of $\mathrm{CTAB}$ as template and $0.1 \mathrm{M} \mathrm{NaNO}_{3}$ was prepared. The $\mathrm{pH}$ was adjusted to 3 by adding $0.1 \mathrm{M}$ $\mathrm{HCl}$. After a first step of hydrolysis for $2.5 \mathrm{~h}$, a cathodic potential of $-1.3 \mathrm{~V}$ was applied for $20 \mathrm{~s}$ to the ITO working electrode with subsequent deposition of the silica layer. The electrode surface was thoroughly rinsed with water and aged overnight at $130^{\circ} \mathrm{C}$. Template extraction was performed by immersing the film electrode in an ethanol solution containing $0.1 \mathrm{M} \mathrm{HCl}$ for 15 $\min$.

EASA was also used to afford the generation of amino-functionalized mesoporous silica thin films under potentiostatic conditions on ITO plates but the procedure has to be somewhat adapted due to the intrinsic basic properties of (3-aminopropyl)triethoxysilane (APTES) ${ }^{6} 0.2 \mathrm{mmol}$ of APTES were added to a solution made of $10 \mathrm{~mL}$ ethanol and $10 \mathrm{~mL}$ aqueous solution of $0.1 \mathrm{M} \mathrm{NaNO}_{3}$, and its $\mathrm{pH}$ was adjusted to 3 by adding $1.0 \mathrm{M} \mathrm{HCl}$. Then, $1.8 \mathrm{mmol}$ of TEOS and $0.64 \mathrm{mmol}$ of CTAB were added to the solution. The sol was aged for $2.5 \mathrm{~h}$ under stirring before use. A cathodic 
potential of $-1.3 \mathrm{~V}$ was applied for $20 \mathrm{~s}$. The electrode was rinsed quickly with deionized water. The silica film obtained was aged overnight in an oven at $130^{\circ} \mathrm{C}$. Prior to use, template extraction was made as above.

\subsection{Apparatus}

Electrochemical data were obtained using an EG \& G 273 A driven by a PC with the M270 software. A one-compartment cell with a standard three-electrode configuration was used for cyclic voltammetry $(\mathrm{CV})$ experiments. The reference electrode was a saturated calomel electrode (SCE) separated from the bulk electrolyte solution via fritted compartments filled with the same electrolyte; the counter electrode was a platinum gauze of large surface area. The working electrode was an indium-tin oxide plate. Cyclic voltammograms have been recorded at $20 \mathrm{mV} \mathrm{s}^{-1}$ (unless specified otherwise) from aqueous solutions of the POM at selected $\mathrm{pH}$ values and ionic strengths adjusted using $\mathrm{H}_{2} \mathrm{SO}_{4}$ and/or $\mathrm{Na}_{2} \mathrm{SO}_{4}$.

\section{Results and discussion}

\subsection{Preliminary considerations}

The electrochemical behavior of a Keggin-type heteropolyanion, $\left[\mathrm{SiW}_{12} \mathrm{O}_{40}\right]^{4-}$ has been first checked on bare indium-tin oxide (ITO) electrode (Figure 2). The measurements have been carried out in acidic media, within a $\mathrm{pH}$ range that will be investigated later on with the silica film modified electrodes

A series of electrochemical experiments have been performed concerning the reduction of $\left[\mathrm{SiW}_{12} \mathrm{O}_{40}\right]^{4-}$ in an aqueous electrolyte solution consisting of different compositions of $\mathrm{H}_{2} \mathrm{SO}_{4}+$ 
$\mathrm{Na}_{2} \mathrm{SO}_{4}$ in the $\mathrm{pH}$ range from 1 to 3 (Figure 2). Cyclic voltammograms of $\left[\mathrm{SiW}_{12} \mathrm{O}_{40}\right]^{4-}$ recorded on bare ITO involve three reversible processes corresponding to the reduction of $\mathrm{W}$ centers: two initial reversible single-electron processes (I and II) followed by an overall two-electron step (process III).

$\left[\mathrm{SiW}_{12} \mathrm{O}_{40}\right]^{4-}+1 \mathrm{e}^{-} \rightarrow\left[\mathrm{SiW}_{12} \mathrm{O}_{40}\right]^{5-}$

Process I

$\left[\mathrm{SiW}_{12} \mathrm{O}_{40}\right]^{5-}+1 \mathrm{e}^{-} \rightarrow\left[\mathrm{SiW}_{12} \mathrm{O}_{40}\right]^{6-}$

Process II

$\left[\mathrm{SiW}_{12} \mathrm{O}_{40}\right]^{6-}+2 \mathrm{e}^{-}+2 \mathrm{H}^{+} \rightarrow\left[\mathrm{H}_{2} \mathrm{SiW}_{12} \mathrm{O}_{40}\right]^{6-}$

Process III

The half-wave potentials $\mathrm{E}_{1 / 2}$ for I and II are essentially independent of $\mathrm{pH}$. In contrast, $\mathrm{E}_{1 / 2}$ for the third process shifted to more negative values with increasing $\mathrm{pH}$. Such electrochemical behavior is analogous to the one previously described using glassy carbon as a working electrode. ${ }^{38}$
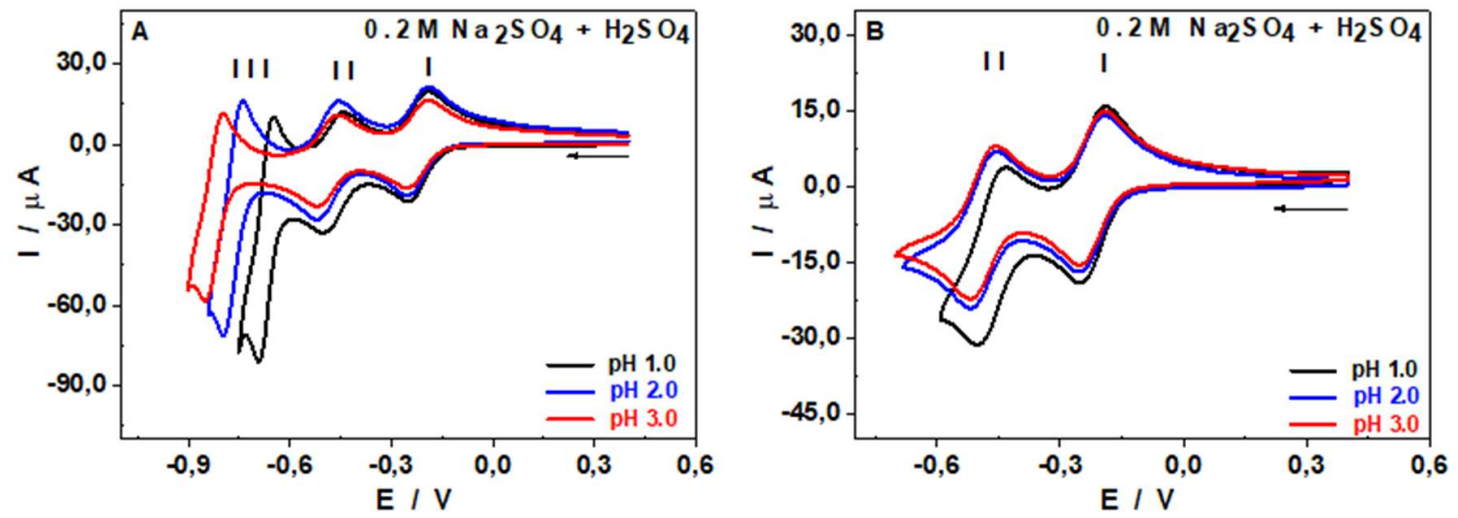

Figure 2. Cyclic voltammograms recorded on bare ITO electrode in a solution containing $5.0 \times 10^{-4} \mathrm{M}\left[\mathrm{SiW}_{12} \mathrm{O}_{40}\right]^{4-}$ and $0.2 \mathrm{M} \mathrm{Na}_{2} \mathrm{SO}_{4}+\mathrm{H}_{2} \mathrm{SO}_{4}$ at different concentrations adjusted to fix $\mathrm{pH}$ values at 0.3 (black line), 1.0 (red line), 2.0 (blue line) and 3.0 (green line). Part A represents the whole potential window while part B is restricted to that of the two first redox processes. 
The vertically-aligned silica films prepared are characterized by their mesoporous channels network uniformly and densely packed in a hexagonal arrangement (Figure 1B). The pore diameter when using $\mathrm{CTAB}$ as surfactant is of $2.1 \mathrm{~nm}$ and the thickness of the silica thin film is close to 100 $\mathrm{nm}$ (Figure 1C). Their presence onto the ITO electrode surface is likely to affect the above voltammetric processes. Indeed, the electrochemical behavior of ionic compounds on silica films is strongly influenced by their own charge and size, and the charge density of the silica walls..$^{35,43}$ To our knowledge most of the work previously reported in the study of the mass transport of charged species through mesoporous channels has been performed at $\mathrm{pH}$ higher than the isoelectronic point of silica. Typically in these conditions, cationic redox probes such as $\mathrm{Ru}(\mathrm{NH}) 6^{3+}$ exhibit an accumulation phenomenon due to electrostatic attractions with negatively charged silica walls at $\mathrm{pH}$ higher than 3 , whereas some repulsion effects were observed in more acidic media (detailed analysis of the electrochemical response of this redox probe as a function of $\mathrm{pH}$ is presented in Fig. S3, see SI). One can thus expect an opposite behavior for the $\left[\mathrm{SiW}_{12} \mathrm{O}_{40}\right]^{4-}$ anion. In the context of a charged surface in an electrolytic solution, the thickness of the double layer that forms at the charged surface is called the Debye length $\left(\lambda_{D}\right)$. It is known as the shielding distance as it represents the distance over which the charged surface is shielded from the bulk and can be expressed as $\quad \lambda_{\mathrm{D}}=\sqrt{\frac{\varepsilon_{0} \varepsilon_{r} K_{B} T}{2 N_{A} q^{2} I}} \quad$ Equation 1

Where $\varepsilon_{0}$ is the vacuum permittivity $\left(8.85 \times 10^{-12} \cdot \mathrm{m}^{-1}\right), \varepsilon_{r}$ is the relative permittivity of water $(7.84$ x $10^{-10} \mathrm{~F} . \mathrm{m}^{-1}$ at $\left.25^{\circ} \mathrm{C}\right)$ also called dielectric constant, $K_{B}$ is the Boltzmann constant $\left(1.38 \times 10^{-23}\right.$ $\left.\mathrm{J} . \mathrm{K}^{-1}\right), T$ is the temperature in $\mathrm{K}, \mathrm{q}$ is the charge of an electron, $I$ is the ionic strength and $N_{A}$ is the 
Avogadro number $\left(6.02 \times 10^{23} \mathrm{~mol}^{-1}\right)$. I is referred to as the ionic strength. The Debye length is proportional to the reciprocal of the ionic strength. The larger the concentration of ions, the more they "shield" the charged surface and the thinner the Debye length is. This is represented in figure 1 above by the dotted green line. As the ionic strength increases, the potential drops off faster and the effects of the charged surface are negated quicker (as a function of distance). As can be deduced from equation 1 , the thickness of the double layer is dependent on the electrolyte concentration and can be estimated from the Debye-Hückel length (i.e., respectively $10 \mathrm{~nm}, 3 \mathrm{~nm}, 1 \mathrm{~nm}$ and 0.3 $\mathrm{nm}$ for electrolyte concentrations of $1 \mathrm{mM}, 10 \mathrm{mM}, 100 \mathrm{mM}$ and $1 \mathrm{M}) .{ }^{44}$

\subsection{Electrochemical behavior of $\left[\mathrm{SiW}_{12} \mathrm{O}_{40}\right]^{4-}$ on mesoporous silica film modified ITO electrode in highly acidic media}

\subsubsection{Cyclic voltammetry (CV) at $\mathrm{pH} 0.3$ to 1.0}

Figure 3 shows typical CV curves recorded at pH 0.3 (Fig. 3A) and $\mathrm{pH} 1$ (Fig. 3B). Compared to bare ITO, the two successive monoelectronic processes (located at $-0.26 \mathrm{~V}$ and $-0.49 \mathrm{~V}$ ) and the bielectronic step (at $-0.65 \mathrm{~V}$ ) occur at approximately the same potential values on the surfactantfree mesoporous silica film electrode (prior to CTAB extraction, no signal can been seen (red curve on Fig. 3A), confirming that the silica film is free of holes/defects). At $\mathrm{pH} 0.3$, the modified electrode exhibits much larger peak currents compared to the ones obtained on bare ITO in $0.5 \mathrm{M}$ $\mathrm{H}_{2} \mathrm{SO}_{4}$ (compare blue and black lines in Fig. 3A). This significant increase of the peak currents up to $\mathrm{I}_{\text {film }} / \mathrm{I}_{\mathrm{ITO}}=2.2$ (for the first signal) is attributed to an accumulation phenomenon due to favorable interactions between $\left[\mathrm{SiW}_{12} \mathrm{O}_{40}\right]^{4-}$ species and the silica walls that are positively charged in $0.5 \mathrm{M}$ $\mathrm{H}_{2} \mathrm{SO}_{4}$. The situation is different at $\mathrm{pH} 1$ where a small decrease in the CV signals with respect to 
bare ITO is observed (Fig. 3B). Although the silica walls are still positively charged at pH 1.0, one can expect a lower charge density than at $\mathrm{pH} 0.3$, leading to a smaller accumulation power. It is also noteworthy that the ionic strength is different in these cases $\left(0.1 \mathrm{M}\right.$ or $\left.0.5 \mathrm{M} \mathrm{H}_{2} \mathrm{SO}_{4}\right)$, inducing a thicker electrical double layer (EDL) in more diluted $\mathrm{H}_{2} \mathrm{SO}_{4}$ (i.e., larger Debye length), resulting in more restricted mass transport through the film at $\mathrm{pH} 1$ and thus less intense $\mathrm{CV}$ peaks.
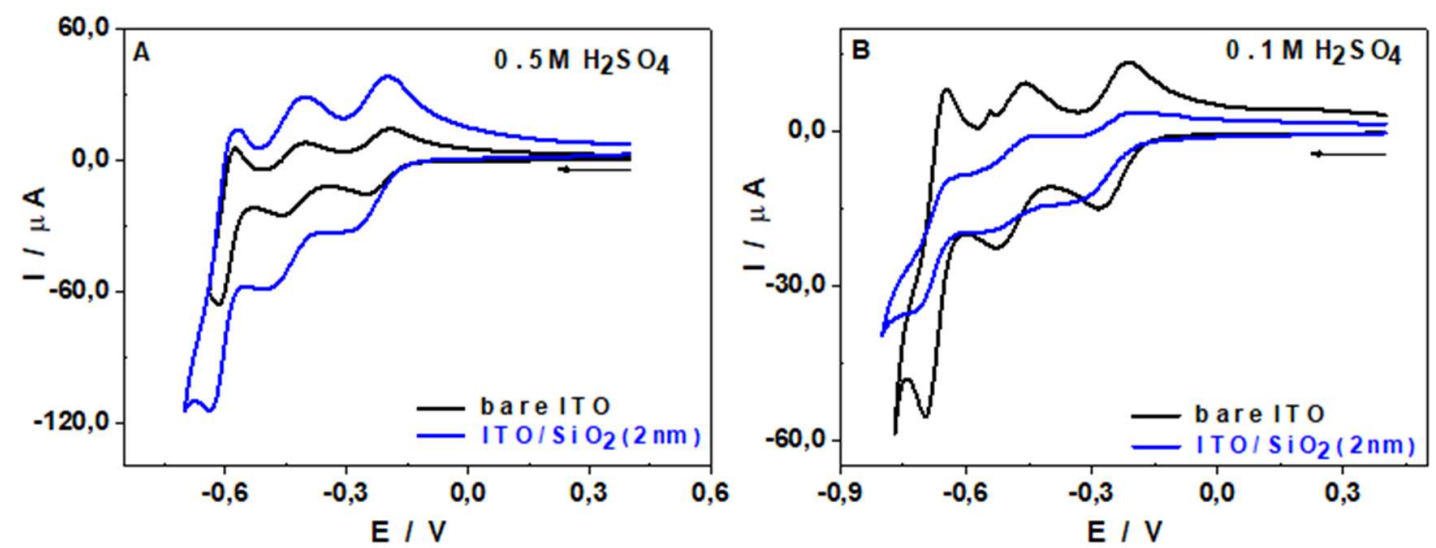

Figure 3. Cyclic voltammograms recorded in a solution containing $5.0 \times 10^{-4} \mathrm{M}\left[\mathrm{SiW}_{12} \mathrm{O}_{40}\right]^{4-}$ and $\mathrm{H}_{2} \mathrm{SO}_{4}$ at concentrations adjusted to fix $\mathrm{pH}$ values at 0.3 (A) or 1.0 (B) using bare ITO electrode (black) and ITO covered with a mesoporous silica film after surfactant extraction (blue); a control experiment performed prior to surfactant extraction is also shown in red on part A of the figure.

\subsubsection{Effect of ionic strength at $\mathrm{pH} 0.3$ to 1.0}

Effect of the ionic strength of the solution has been investigated by adding $\mathrm{Na}_{2} \mathrm{SO}_{4}$ to the above media and typical results are illustrated in Figure 4, showing the variation in intensity of the first voltammetric signal when passing from bare ITO to the film electrode. No significant changes in terms of peak current and peak potential values are observed on the electrochemical response of 
$\left[\mathrm{SiW}_{12} \mathrm{O}_{40}\right]^{4-}$ on bare ITO when increasing the ionic strength of the electrolyte (see black lines in Figure 4). In contrast, noticeable changes of the $\mathrm{CV}$ signals is observed when adding $\mathrm{Na}_{2} \mathrm{SO}_{4}$ to the $\mathrm{H}_{2} \mathrm{SO}_{4}$ solutions. At $\mathrm{pH} 0.3$, one can see an important decrease in peak intensity when adding increasing amounts of $\mathrm{Na}_{2} \mathrm{SO}_{4}$ in the medium (compare parts A-C in Figure 4), which can be assigned to a competition between the anionic electroactive species and the increasing amounts of $\mathrm{SO}_{4}{ }^{2-}$ provided by both $\mathrm{H}_{2} \mathrm{SO}_{4}$ and $\mathrm{Na}_{2} \mathrm{SO}_{4}$ in the electrolyte solution. The effect is more drastic in $0.5 \mathrm{M} \mathrm{H}_{2} \mathrm{SO}_{4}+0.3 \mathrm{M} \mathrm{Na}_{2} \mathrm{SO}_{4}$ which corresponds to an ionic strength of $1.4 \mathrm{M}$. Media with ionic strength lower than $0.5 \mathrm{M}$ cannot be checked at this $\mathrm{pH}$ value since $0.5 \mathrm{M} \mathrm{H}_{2} \mathrm{SO}_{4}$ solution is the minimum concentration required to reach this $\mathrm{pH}$.
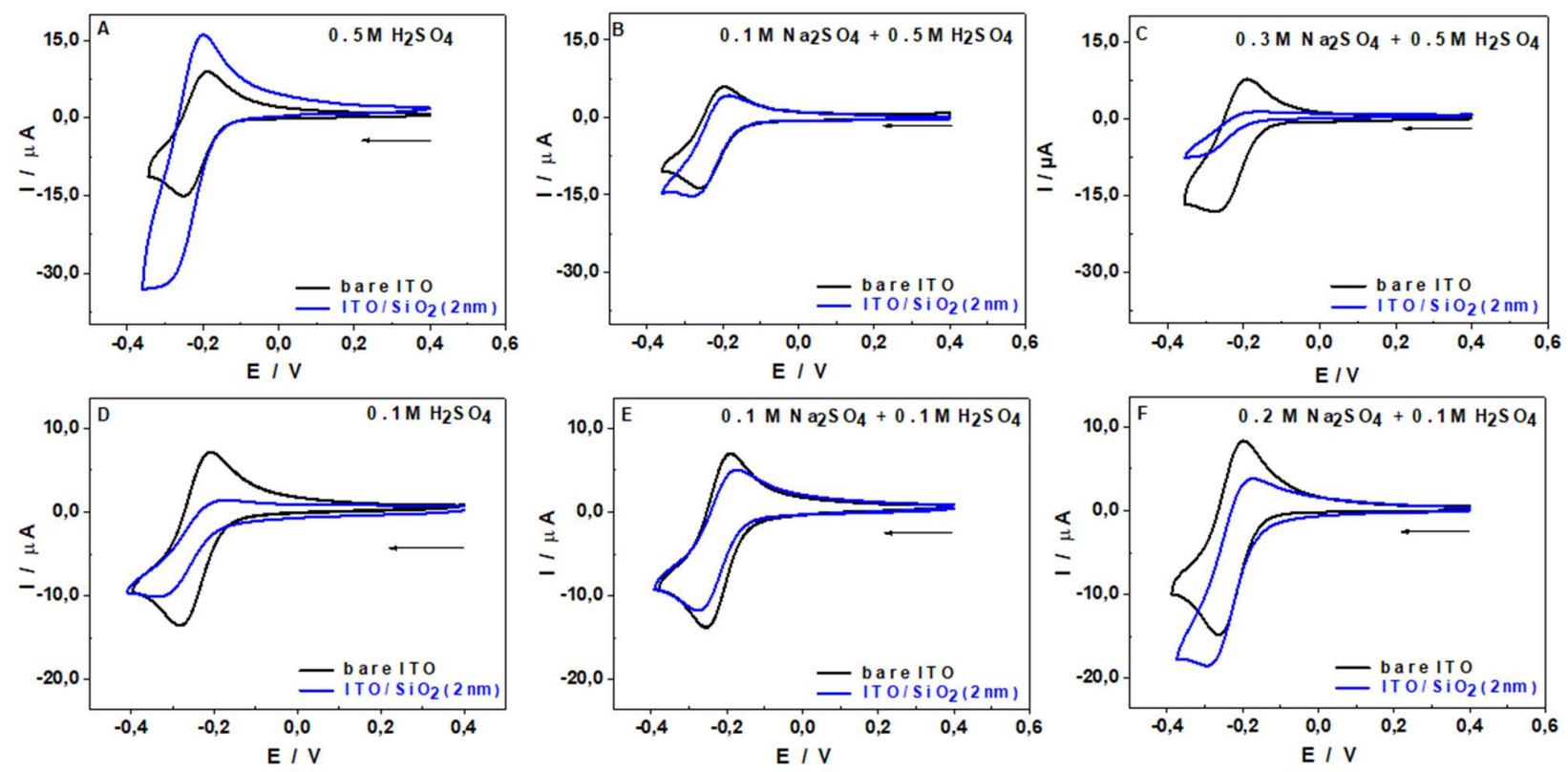

Figure 4. Cyclic voltammograms recorded in a solution containing $5.0 \times 10^{-4} \mathrm{M}\left[\mathrm{SiW}_{12} \mathrm{O}_{40}\right]^{4-}$ and $\mathrm{H}_{2} \mathrm{SO}_{4}$ at concentrations adjusted to fix $\mathrm{pH}$ values at 0.3 (A-C) or 1.0 (D-F) and $\mathrm{Na}_{2} \mathrm{SO}_{4}$ at selected concentrations (see on plots) to get various ionic strengths, using bare ITO electrode (black) and ITO covered with a mesoporous silica film after surfactant extraction (blue). Electrolyte media 
composition: $0.5 \mathrm{M} \mathrm{H}_{2} \mathrm{SO}_{4}(\mathrm{~A}) ; 0.5 \mathrm{M} \mathrm{H}_{2} \mathrm{SO}_{4}+0.1 \mathrm{M} \mathrm{Na}_{2} \mathrm{SO}_{4}(\mathrm{~B}) ; 0.5 \mathrm{M} \mathrm{H}_{2} \mathrm{SO}_{4}+0.3 \mathrm{M} \mathrm{Na}_{2} \mathrm{SO}_{4}$ (C); $0.1 \mathrm{M} \mathrm{H}_{2} \mathrm{SO}_{4}$ (D), 0.1M H $\mathrm{SO}_{4}+0.10 \mathrm{M} \mathrm{Na}_{2} \mathrm{SO}_{4}$ (E); $0.1 \mathrm{M} \mathrm{H}_{2} \mathrm{SO}_{4}+0.2 \mathrm{M} \mathrm{Na}_{2} \mathrm{SO}_{4}$ (F).

At $\mathrm{pH}$ 1.0, the silica walls are still positive but the charge density is expected to be smaller than at $\mathrm{pH} 0.3$ (resulting in lower response of $\left[\mathrm{SiW}_{12} \mathrm{O}_{40}\right]^{4-}$, as discussed above), and the ionic strength of the starting solution (i.e., before adding $\mathrm{Na}_{2} \mathrm{SO}_{4}$ ) is also smaller. In that case ( $\mathrm{pH}$ 1.0), small amounts of added $\mathrm{Na}_{2} \mathrm{SO}_{4}$ result first in some increase of peak currents (up to $0.2 \mathrm{M} \mathrm{Na}_{2} \mathrm{SO}_{4}$, see parts D-F in Figure 4) and then lead to some decrease at higher ionic strengths (see Table 1). Starting from a $\mathrm{I}_{\text {film }} / \mathrm{I}_{\text {ITO }}$ ratio of 0.70 in $0.1 \mathrm{M} \mathrm{H}_{2} \mathrm{SO}_{4}$ alone, it raises to 0.95 and 1.25 when adding 0.1 and $0.2 \mathrm{M} \mathrm{Na}_{2} \mathrm{SO}_{4}$, respectively, and then decreases down to 0.60 in $0.3 \mathrm{M} \mathrm{Na}_{2} \mathrm{SO}_{4}$. One can interpret these results on the basis of two parameters that are likely to affect the accumulation and transport of $\left[\mathrm{SiW}_{12} \mathrm{O}_{40}\right]^{4-}$ species in the nanochannels. First, an increase of the ionic strength leads to a decrease in the thickness of the electrical double layer (EDL), contributing to facilitate free diffusion in the region outside the EDL generated adjacent to the positively charged silica walls ${ }^{45}$ (to counterbalance the surface charge, see illustration on scheme 1), and thereby to more intense voltammetric signals for $\left[\mathrm{SiW}_{12} \mathrm{O}_{40}\right]^{4-}$. The extent of the EDL can be approximately predicted by the Debye length $\lambda_{\mathrm{D}}$, which depends on the molar concentration of the electrolyte and its thickness $\lambda_{\mathrm{D}}$ can be estimated by means of the Debye-Hückel parameter $\kappa$ (Equation 1$)$. When passing from an ionic strength of $0.1 \mathrm{M}$ to $1.0 \mathrm{M}, \lambda_{\mathrm{D}}$ decreases from $1 \mathrm{~nm}$ to $0.3 \mathrm{~nm}$; on the basis of a mesopore diameter of $2.1 \mathrm{~nm}$, it is therefore necessary to increase the ionic strength above $0.1 \mathrm{M}$ to open a free diffusion zone in the nanochannels. However, increasing too much the electrolyte concentration in the medium (e.g., above $0.1 \mathrm{M} \mathrm{Na}_{2} \mathrm{SO}_{4}$ ) contributes to enhance the competition between $\left[\mathrm{SiW}_{12} \mathrm{O}_{40}\right]^{4-}$ and $\mathrm{SO}_{4}{ }^{2-}$ anions for the positive sites in the film, resulting in a decrease in the voltammetric signals, as already discussed for $\mathrm{pH} 0.3$ (Table 1). The best ionic strength has 
thus to be found as a compromise between a value high enough to keep the EDL as thin as possible (and the free diffusion zone as large as possible in the nanochannels) but not too high to avoid competition of the electrolyte anions on the accumulation of $\left[\mathrm{SiW}_{12} \mathrm{O}_{40}\right]^{4-}$ species in the film.

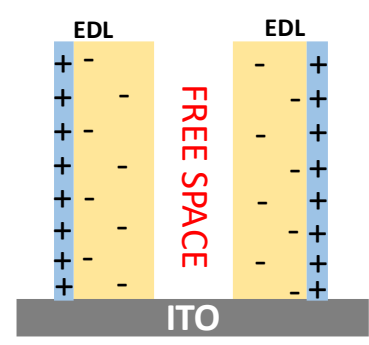

Lower ionic strength

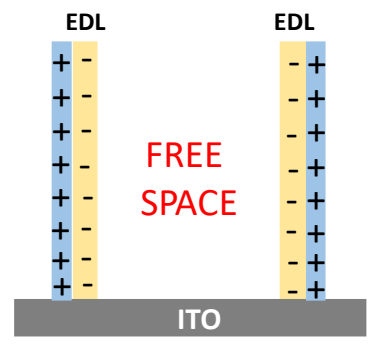

Higher ionic strength

Scheme 1. Schematic representation of the nanochannels in highly acidic medium (where the low $\mathrm{pH}$ induces positive charges on the silica walls) as a function of the ionic strength.

Note that the enhanced electrochemical response reaches a maximum in $0.1 \mathrm{M} \mathrm{H}_{2} \mathrm{SO}_{4} / 0.2 \mathrm{M}$ $\mathrm{Na}_{2} \mathrm{SO}_{4}$ solution for which an accumulation of the anionic electroactive species is observed on a silica thin film compared to ITO in a similar way as previously described at $\mathrm{pH} 0.3$. Both media has a similar ionic strength, however in this case the ratio $\mathrm{I}_{\text {film }} / \mathrm{I}_{\mathrm{ITO}}$ is about 1.3 which is quite smaller than the 2.2 observed at $\mathrm{pH} 0.3$. The difference can be attributed to the lower positive charge density at $\mathrm{pH} 1$ compared to $\mathrm{pH} 0.3$.

\subsubsection{Behavior of an amino-functionalized mesoporous silica film}

Attempts to enhance the accumulation process have been also made by using an aminofunctionalized silica film (i.e., containing ammonium moieties inside the mesochannels of the silica layer as the amine groups are protonated at $\mathrm{pH} 0.3$ and 1.0). Such increase in the positive 
charge density could favor even more the electrostatic interactions with the anionic POMs and contribute to enhance the amplification of their electrochemical response. However, the voltammetric peaks assigned to the electrochemical reduction of the $\left[\mathrm{SiW}_{12} \mathrm{O}_{40}\right]^{4-}$ became lower than observed on a non-modified silica thin film without any enhancement with respect to the bare electrode $\left(\mathrm{I}_{\mathrm{film}} / \mathrm{I}_{\mathrm{ITO}}=0.7\right.$ in the best cases, see Table 1$)$. This can be explained by stronger resistance to mass transport of the electroactive species through the nanochannels (as otherwise reported for organically-functionalized mesoporous silica films ${ }^{8,9}$ ), which is not compensated here by the larger number of positive sites.

\subsubsection{Desorption of the $\left[\mathrm{SiW}_{12} \mathrm{O}_{40}\right]^{4-}$}

Multiple successive cyclic voltammetry measurements have been performed using a $\left[\mathrm{SiW}_{12} \mathrm{O}_{40}\right]^{4-}$ loaded film electrode immersed in POM-free solutions of different compositions of electrolyte in order to determine de the dependence of the desorption of $\left[\mathrm{SiW}_{12} \mathrm{O}_{40}\right]^{4-}$ as a function of $\mathrm{pH}$ and ionic strength of the medium. To this aim, the experiments have been carried out in conditions leading to the most important accumulation phenomenon of $\left[\mathrm{SiW}_{12} \mathrm{O}_{40}\right]^{4-}$ (i.e., $\mathrm{pH} 0.3,0.5 \mathrm{M}$ $\mathrm{H}_{2} \mathrm{SO}_{4}$ ), as obtained from recording up to 50 successive voltammetric scans (at $100 \mathrm{mV} \mathrm{s}^{-1}$ ) with the mesoporous silica film electrode in $0.5 \mathrm{mM}\left[\mathrm{SiW}_{12} \mathrm{O}_{40}\right]^{4-}$. Subsequent desorption has been monitored by multisweep cyclic voltammetry after transferring the electrode into the various POM-free electrolytic solutions, and variations of the first cathodic peak currents with the number of CV scans have been plotted (Figure 5).

Depending on the solution composition $\left(0.5 \mathrm{M} \mathrm{H}_{2} \mathrm{SO}_{4}(\mathrm{pH}=0.3) ; 0.1 \mathrm{M} \mathrm{H}_{2} \mathrm{SO}_{4}(\mathrm{pH}=1) ; 0.1 \mathrm{M}\right.$ $\left.\mathrm{H}_{2} \mathrm{SO}_{4}+0.1 \mathrm{M} \mathrm{Na}_{2} \mathrm{SO}_{4}(\mathrm{pH}=1) ; 0.1 \mathrm{M} \mathrm{H}_{2} \mathrm{SO}_{4}+0.2 \mathrm{M} \mathrm{Na}_{2} \mathrm{SO}_{4}(\mathrm{pH}=1)\right)$, distinct variations can be seen. At $\mathrm{pH}$ 0.3, which corresponds to the solution of lowest $\mathrm{pH}$ and quite high ionic strength, 
an extremely fast decrease in cathodic peak currents $\left(\mathrm{I}_{\mathrm{pc}}\right)$ is observed, and $\mathrm{I}_{\mathrm{pc}}$ values rapidly reach a steady-state value at ca. $15 \%$ of its initial intensity, suggesting that most $\left[\mathrm{SiW}_{12} \mathrm{O}_{40}\right]^{4-}$ species have been removed from the film. Such fast desorption process is explained by the ion exchange of $\left[\mathrm{SiW}_{12} \mathrm{O}_{40}\right]^{4-}$ for $\mathrm{SO}_{4}{ }^{2-}$ anions from the electrolyte. The situation is significantly different at $\mathrm{pH}$ 1 , which corresponds to the solution of lowest ionic strength, where desorption of $\left[\mathrm{SiW}_{12} \mathrm{O}_{40}\right]^{4-}$ is much less (steady-state $\mathrm{I}_{\mathrm{pc}}$ values around $85 \%$ of their initial intensity). This is due to the lesser amount of competing $\mathrm{SO}_{4}{ }^{2-}$ anions, and to the rather strong affinity of the bulky $\left[\mathrm{SiW}_{12} \mathrm{O}_{40}\right]^{4-}$ anions for the positively charged nanochannels. Intermediate behavior is observed when adding $\mathrm{Na}_{2} \mathrm{SO}_{4}$ to the $\mathrm{pH} 1$ solution, with lower steady-state $\mathrm{I}_{\mathrm{pc}}$ values for higher ionic strengths, as a result of increasing the amount of competing $\mathrm{SO}_{4}{ }^{2-}$ anions into the solution. By controlling the ionic strength, it is therefore possible to tune the amount of $\left[\mathrm{SiW}_{12} \mathrm{O}_{40}\right]^{4-}$ keeping adsorbed into the film and exhibiting a stable CV response upon multiple potential scans.

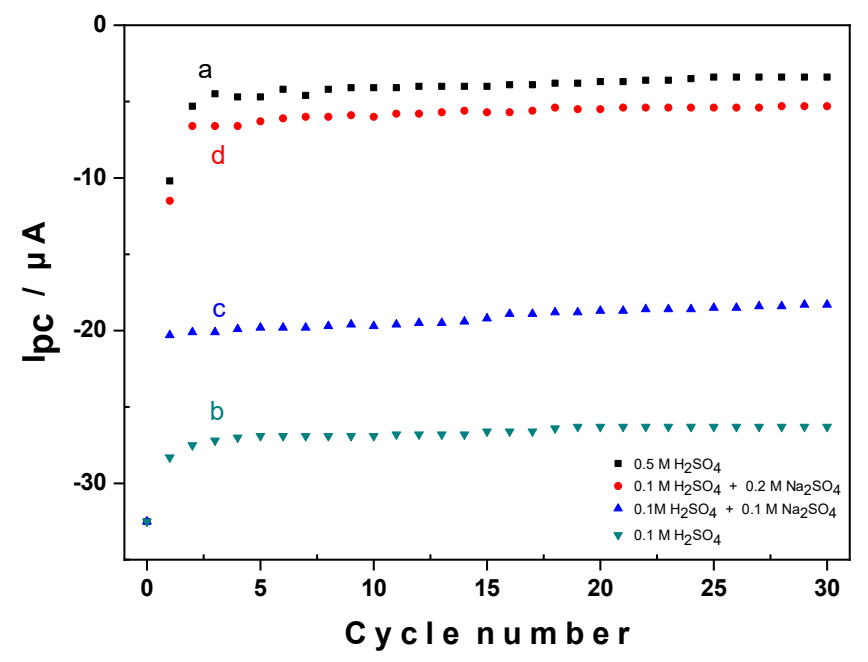

Figure 5. Variation of the intensity of the first cathodic peak currents obtained after transferring an electrode pretreated for 50 successive $\mathrm{CV}$ scans in $0.5 \mathrm{mM}\left[\mathrm{SiW}_{12} \mathrm{O}_{40}\right]^{4-}$ to a POM-free solution, 
expressed as a function of the number of voltammetric scans recorded in electrolyte media of various compositions: $0.5 \mathrm{M} \mathrm{H}_{2} \mathrm{SO}_{4}(\mathrm{a}) ; 0.1 \mathrm{M} \mathrm{H}_{2} \mathrm{SO}_{4}(\mathrm{~b}) ; 0.1 \mathrm{M} \mathrm{H}_{2} \mathrm{SO}_{4}+0.1 \mathrm{M} \mathrm{Na}_{2} \mathrm{SO}_{4}$ (c); 0.1 $\mathrm{M} \mathrm{H}_{2} \mathrm{SO}_{4}+0.2 \mathrm{M} \mathrm{Na}_{2} \mathrm{SO}_{4}(\mathrm{~d})$.

\subsection{Electrochemical behavior of $\left[\mathrm{SiW}_{12} \mathrm{O}_{40}\right]^{4-}$ on mesoporous silica film modified ITO electrode in slightly acidic media}

\subsection{1. $\mathrm{CV}$ and effect of ionic strength at $\mathrm{pH} 2$ and 3}

The electrochemical behavior of $\left[\mathrm{SiW}_{12} \mathrm{O}_{40}\right]^{4-}$ has been subsequently studied at $\mathrm{pH} 2$ and 3, where the silica walls contain less silanolate groups and might be neutral or slightly negatively charged. In these conditions, less pronounced electrostatic interactions are expected to affect the transport of POM species through the film. Figure 6 shows typical $\mathrm{CV}$ curves for $\left[\mathrm{SiW}_{12} \mathrm{O}_{40}\right]^{4-}$ at $\mathrm{pH} 2$. The ionic strength of the media has been varied by addition of $\mathrm{Na}_{2} \mathrm{SO}_{4}$. In the absence of $\mathrm{Na}_{2} \mathrm{SO}_{4}$ (Fig. $6 \mathrm{~A})$, no noticeable voltammetric signal is observed for $\left[\mathrm{SiW}_{12} \mathrm{O}_{40}\right]^{4-}$ on the silica film electrode at $\mathrm{pH} 2\left(0.01 \mathrm{M} \mathrm{H}_{2} \mathrm{SO}_{4}\right)$. This absence of the cathodic processes is assigned to the very low ionic strength of the medium at $\mathrm{pH} 2$ in the presence of only $\mathrm{H}_{2} \mathrm{SO}_{4}$ which is associated with an increase of the EDL thickness that can even be larger than the mesopore radius (leading to possible overlapping; a Debye length of the order of $\sim 1 \mathrm{~nm}$ can be estimated from equation 1 for an ionic strength of $100 \mathrm{mM})$. By contrast, well-defined voltammetric signals for $\left[\mathrm{SiW}_{12} \mathrm{O}_{40}\right]^{4-}$ progressively grow when adding $0.05 \mathrm{M}$ or $0.1 \mathrm{M} \mathrm{Na}_{2} \mathrm{SO}_{4}$ in the medium (see respectively parts $\mathrm{B} \& \mathrm{C}$ in Figure 6), but the peak currents fail to reach the intensity obtained on bare ITO. This is again due to lowering the EDL thickness and thus enlarging the free diffusion zone in the nanochannels (scheme 1), but the effect is less pronounced than that observed above at $\mathrm{pH} 1$ due 
to few or no accumulation of $\left[\mathrm{SiW}_{12} \mathrm{O}_{40}\right]^{4-}$ on the silica walls. And the situation is even worse at pH 3 where the silica surface is neutral and starts even to become slightly negatively-charged, for which the voltammetric signals reach only ca. $2 / 3$ of their intensity observed on bare ITO (Figure 7). In that case, no favorable interaction is expected between the POM and the silica surface and thus no accumulation of $\left[\mathrm{SiW}_{12} \mathrm{O}_{40}\right]^{4-}$ species into the film, the electrochemical response being essentially controlled by their diffusion through the nanochannels from the solution to the electrode surface.
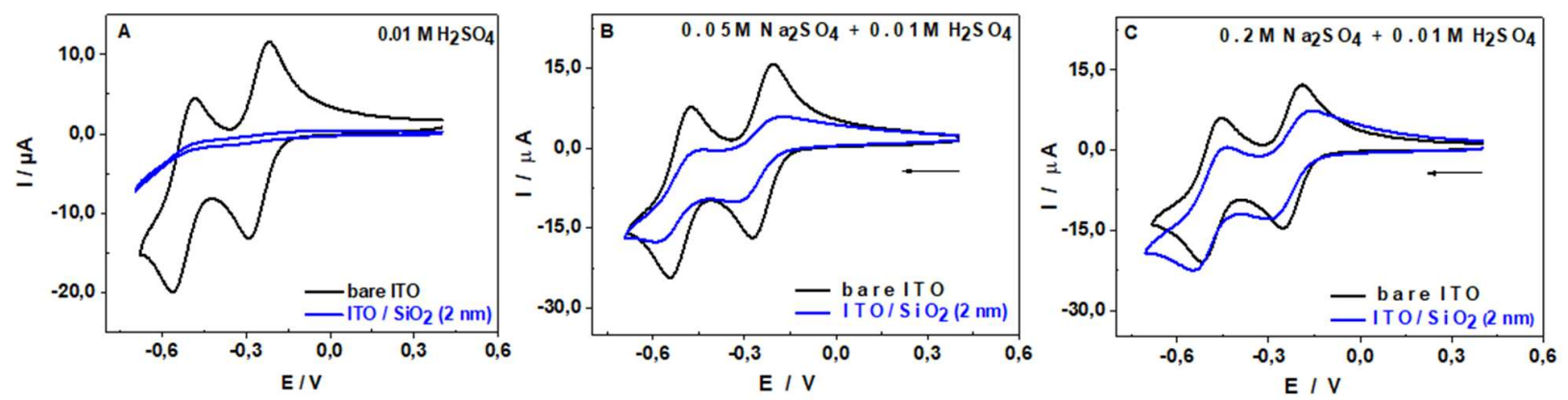

Figure 6. Cyclic voltammograms recorded in a solution containing $5.0 \times 10^{-4} \mathrm{M}\left[\mathrm{SiW}_{12} \mathrm{O}_{40}\right]^{4-}$ at $\mathrm{pH}$ $2\left(0.01 \mathrm{M} \mathrm{H}_{2} \mathrm{SO}_{4}, \mathrm{~A}\right)$ to which increasing amounts of $\mathrm{Na}_{2} \mathrm{SO}_{4}$ have been added $(0.05 \mathrm{M}(\mathrm{B})$ and $0.2 \mathrm{M}(\mathrm{C})$ ), using bare ITO electrode (black) and ITO covered with a mesoporous silica film after surfactant extraction (blue).
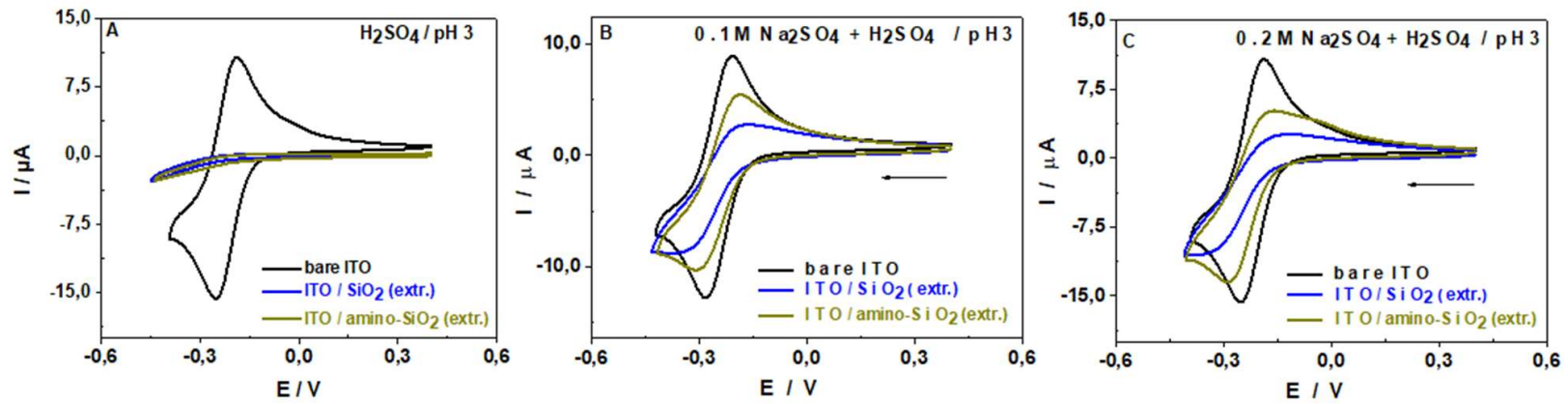
Figure 7. Cyclic voltammograms recorded in a solution containing $5.0 \times 10^{-4} \mathrm{M}\left[\mathrm{SiW}_{12} \mathrm{O}_{40}\right]^{4-}$ and $0.001 \mathrm{M} \mathrm{H}_{2} \mathrm{SO}_{4}$ alone (A), or with $0.1 \mathrm{M} \mathrm{Na}_{2} \mathrm{SO}_{4}$ (B) or $0.2 \mathrm{M} \mathrm{Na}_{2} \mathrm{SO}_{4}$ (C), using bare ITO electrode (black), ITO covered with a mesoporous silica film after surfactant extraction (blue), and an amino-functionalized silica film on ITO (dark green).

A way to improve somewhat the voltammetric response of $\left[\mathrm{SiW}_{12} \mathrm{O}_{40}\right]^{4-}$ is via the introduction of amino functionalities in the silica films, which are positively charged in acidic media. As shown on Figure 7 (dark green curves), this contributes to slightly larger peak currents, suggesting some accumulation behavior arising from the presence of quaternary ammonium groups at $\mathrm{pH} 3$. The effect is however not so overwhelming as these groups attached to the mesopore walls can also lead to steric hindrance that makes more complicated the diffusion of electroactive probes through the nanochannels. In the best case, $\mathrm{I}_{\mathrm{NH} 2 \text {-film }} / \mathrm{I}_{\text {ITO }}$ ratios of about $0.7-0.9$ can be achieved in the presence of added $\mathrm{Na}_{2} \mathrm{SO}_{4}$ in the $0.1-0.3 \mathrm{M}$ concentration range (Table 1).

Table 1. Summary of the ratios of peak current values observed at the film electrodes relative to bare ITO (Irel), respectively for the three cathodic signals observed for $0.5 \mathrm{mM}\left[\mathrm{SiW}_{12} \mathrm{O}_{40}\right]^{4-}$ at a various $\mathrm{pH}$ and ionic strengths. The mesoporous films were respectively made of only silica (TEOS) or functionalized with amino groups $\left(\mathrm{T} / \mathrm{NH}_{2}\right)$. The ionic strength has been estimated considering only the first dissociation of $\mathrm{H}_{2} \mathrm{SO}_{4}$. 
Table 1.

\begin{tabular}{|c|c|c|c|c|c|c|}
\hline \multicolumn{7}{|c|}{$\left[\mathrm{SiW}_{12} \mathrm{O}_{40}\right]^{4-}$} \\
\hline \multicolumn{3}{|c|}{$\mathrm{pH}=0.3$} & & \multicolumn{3}{|c|}{$\mathrm{I}_{\text {rel }}=\mathrm{I}_{\text {film }} / \mathrm{I}_{\mathrm{ITO}}$} \\
\hline$\left[\mathrm{Na}_{2} \mathrm{SO}_{4}\right]$ & {$\left[\mathrm{H}_{2} \mathrm{SO}_{4}\right]$} & I & & $1^{\text {st }}$ wave & $2^{\text {nd }}$ wave & $3^{\text {rd }}$ wave \\
\hline \multirow{2}{*}{0} & \multirow{2}{*}{0.5} & \multirow{2}{*}{0.5} & TEOS & 2.20 & 2.00 & 1.35 \\
\hline & & & $\mathrm{T} / \mathrm{NH}_{2}$ & 0.71 & 0.57 & 0.75 \\
\hline 0.1 & 0.5 & 0.8 & TEOS & 1.00 & 1.00 & 0.70 \\
\hline 0.3 & 0.5 & 1.4 & TEOS & 0.38 & 0.40 & 0.46 \\
\hline \multicolumn{3}{|c|}{$\mathrm{pH}=1.0$} & & \multicolumn{3}{|c|}{$\mathrm{I}_{\text {rel }}=\mathrm{I}_{\text {film }} / \mathrm{I}_{\mathrm{ITO}}$} \\
\hline$\left[\mathrm{Na}_{2} \mathrm{SO}_{4}\right]$ & {$\left[\mathrm{H}_{2} \mathrm{SO}_{4}\right]$} & I & & $1^{\text {st }}$ wave & $2^{\text {nd }}$ wave & $3^{\text {rd }}$ wave \\
\hline 0 & 0.1 & 0.1 & TEOS & 0.70 & 0.40 & 0.40 \\
\hline 0.1 & 0.1 & 0.4 & TEOS & 0.95 & 1.00 & 1.00 \\
\hline \multirow{2}{*}{0.2} & \multirow{2}{*}{0.1} & \multirow{2}{*}{0.7} & TEOS & 1.25 & 1.50 & 0.80 \\
\hline & & & $\mathrm{T} / \mathrm{NH}_{2}$ & 0.74 & 0.56 & 0.70 \\
\hline \multirow{2}{*}{0.3} & \multirow{2}{*}{0.1} & \multirow{2}{*}{1.0} & TEOS & 0.60 & 0.57 & 0.64 \\
\hline & & & $\mathrm{T} / \mathrm{NH}_{2}$ & 0.57 & 0.50 & 0.42 \\
\hline \multicolumn{3}{|c|}{$\mathrm{pH}=2.0$} & & \multicolumn{3}{|c|}{$\mathrm{I}_{\mathrm{rel}}=\mathrm{I}_{\mathrm{film}} / \mathrm{I}_{\mathrm{ITO}}$} \\
\hline$\left[\mathrm{Na}_{2} \mathrm{SO}_{4}\right]$ & {$\left[\mathrm{H}_{2} \mathrm{SO}_{4}\right]$} & I & & $1^{\text {st }}$ wave & $2^{\text {nd }}$ wave & $3^{\text {rd }}$ wave \\
\hline 0.05 & 0.01 & 0.16 & TEOS & 0.60 & 0.50 & 0.56 \\
\hline \multirow{2}{*}{0.2} & \multirow{2}{*}{0.01} & \multirow{2}{*}{0.61} & TEOS & 0.83 & 0.83 & 0.93 \\
\hline & & & $\mathrm{T} / \mathrm{NH}_{2}$ & 0.91 & 1.00 & 1.00 \\
\hline \multicolumn{3}{|c|}{$\mathrm{pH}=3.0$} & & \multicolumn{3}{|c|}{$\mathrm{I}_{\text {rel }}=\mathrm{I}_{\text {film }} / \mathrm{I}_{\text {Іто }}$} \\
\hline$\left[\mathrm{Na}_{2} \mathrm{SO}_{4}\right]$ & {$\left[\mathrm{H}_{2} \mathrm{SO}_{4}\right]$} & I & & $1^{\text {st }}$ wave & $2^{\text {nd }}$ wave & $3^{\text {rd }}$ wave \\
\hline 0.1 & 0.001 & 0.30 & TEOS & 0.72 & 1.02 & 0.94 \\
\hline \multirow{2}{*}{0.2} & \multirow{2}{*}{0.001} & \multirow{2}{*}{0.61} & TEOS & 0.81 & 1.00 & 0.72 \\
\hline & & & $\mathrm{T} / \mathrm{NH}_{2}$ & 0.91 & 0.90 & 0.88 \\
\hline
\end{tabular}




\subsubsection{Film behavior at $\mathrm{pH} 4$}

The electrochemical response of $\left[\mathrm{SiW}_{12} \mathrm{O}_{40}\right]^{4-}$ has been also investigated at $\mathrm{pH} 4.0$ in acetate buffer. At $\mathrm{pH} 4$ the silica films have an important density of negative charges that would make stronger the electrostatic repulsion with $\left[\mathrm{SiW}_{12} \mathrm{O}_{40}\right]^{4-}$. As expected, quasi non-existent and poorly defined signals are observed (Figure 8) as a result of hindered mass transport of these electroactive species through the mesochannels and therefore suppressed electrochemical response. No real effect of the ionic strength is observed. Again, the presence of quaternary ammonium cations onto the silica walls enhances the electrochemical response of $\left[\mathrm{SiW}_{12} \mathrm{O}_{40}\right]^{4-}$ compared to the non-modified silica film. However, even in the case of the amino-functionalized silica film the $\mathrm{I}_{\text {film }} / \mathrm{I}_{\text {ITO }}$ ratio does not reach the value close to the unity. Two reasons could contribute to explain this rather low $\mathrm{I}_{\text {film }} / \mathrm{I}_{\text {ITO }}$ ratio: a first one is that the quaternary ammonium cations are not numerous enough to compensate the negative charge present on the silica walls due to the silanolate groups, and a second one involves steric hindrance for mass transport of $\left[\mathrm{SiW}_{12} \mathrm{O}_{40}\right]^{4-}$ inside the mesopores (partially occupied by the protonated amine groups); probably both phenomena co-exist and it remains difficult to make clear distinction. 

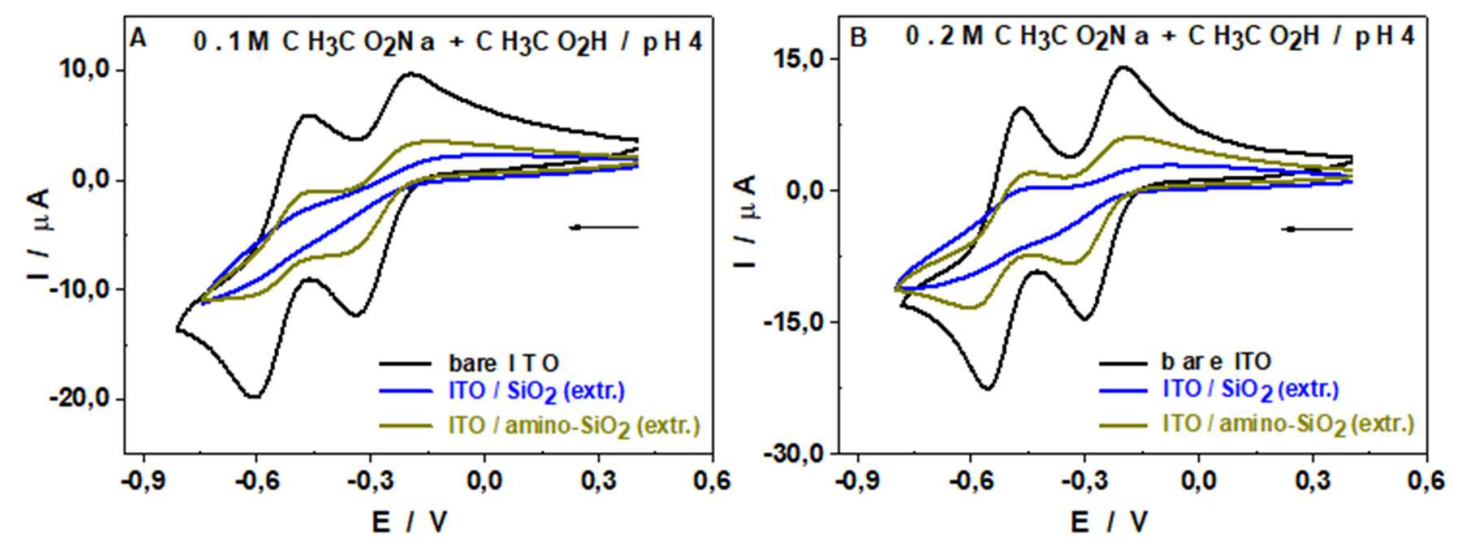

Figure 7. Cyclic voltammograms of $5.0 \times 10^{-4} \mathrm{M}\left[\mathrm{SiW}_{12} \mathrm{O}_{40}\right]^{4-}$ in acetate buffer at $\mathrm{pH} 4.0(0.1 \mathrm{M}$ (A) or $0.2 \mathrm{M}(\mathrm{B})$ ), using bare ITO electrode (black) and ITO covered with a mesoporous silica film after surfactant extraction (blue).

\section{Concluding remarks}

The voltammetric response of $\left[\mathrm{SiW}_{12} \mathrm{O}_{40}\right]^{4-}$ has been studied using ITO electrodes covered with vertically-oriented mesoporous silica films. The results have demonstrated on one hand, the possibility to get well-defined electrochemical signals for such a bulky anion and, on the other hand, a significant influence of $\mathrm{pH}$ and ionic strength of the medium on these processes. The effect of $\mathrm{pH}$ is illustrated on Scheme 2. Taking into account the amphoteric character of silica, the surface of mesopore walls can be either positive (due to $\equiv \mathrm{SiOH}_{2}{ }^{+}$functions, prominent at $\mathrm{pH}<2$ ), neutral (mainly $\equiv \mathrm{SiOH}$ groups at $\mathrm{pH} 2-3$ ), or negative (due to $\equiv \mathrm{SiO}^{-}$at $\mathrm{pH}>3$ ). As a consequence, $\mathrm{POM}$ anions were likely to be accumulated only in very acidic media, leading to large CV peaks (as large as low was the $\mathrm{pH}$ ), whereas the electrochemical responses were suppressed at $\mathrm{pH}$ above 3 due to electrostatic repulsions from the negatively charged mesopore channels (it is possible to 
circumvent somewhat this limitation by introducing positive charges by functionalization with propylammonium moieties but their presence in the small channels contributed to induce some resistance to mass transport and thus moderately intense peak currents). An intermediate behavior was observed on neutral films ( $\mathrm{pH} 2-3)$ for which $\left[\mathrm{SiW}_{12} \mathrm{O}_{40}\right]^{4-}$ species were able to cross the film without noticeable accumulation/rejection phenomena. Ionic strength also played an important role. As illustrated on Scheme 3, it has to be high enough to enable the existence of a free diffusion zone in the small channels (thanks to narrow EDL layers), and thus large voltammetric signals, but not too high to avoid competition of the electrolyte anions with the $\left[\mathrm{SiW}_{12} \mathrm{O}_{40}\right]^{4-}$ probes for the binding sites (which resulted in lower current intensities).

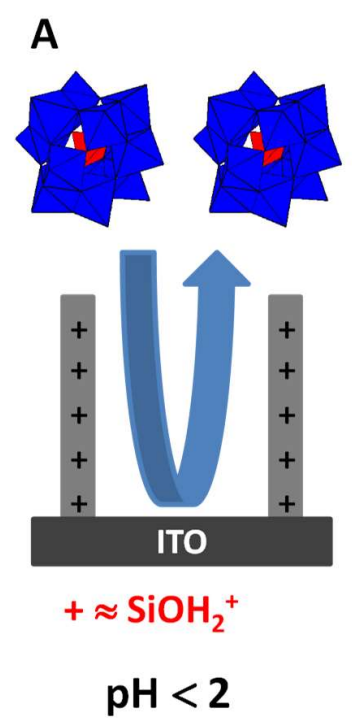

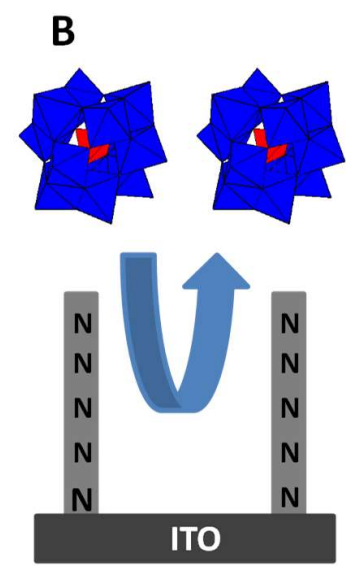

$\mathrm{N} \approx \mathrm{SiOH}$

pH 2-3
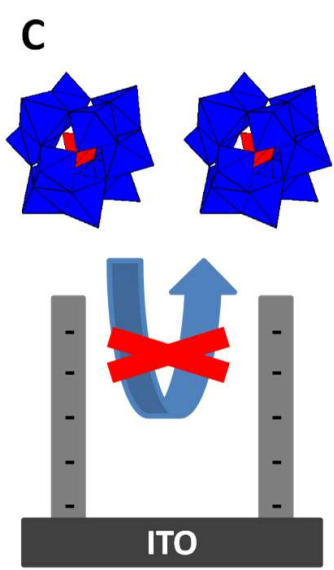

$-\approx \mathrm{SiO}^{-}$

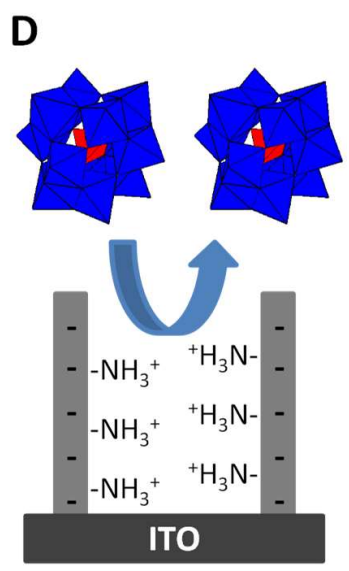

$\mathrm{pH}>3$

Scheme 2. Schematic illustration of the surface charge of silica nanochannels as a function of $\mathrm{pH}$ and their effect on the film permeability to the anionic redox probes. A) $\mathrm{pH}<\mathrm{pI}$ : Positive charge density. B) $\mathrm{pH}=\mathrm{pI}$ : Neutral silica. C) $\mathrm{pH}>\mathrm{pI}$ : Negative charge density. D) Amino-functionalized silica film at $\mathrm{pH}>\mathrm{pI}$ (protonated at $\mathrm{pH}$ lower than the $\mathrm{pKa}$ of $\sim 10$ ). 


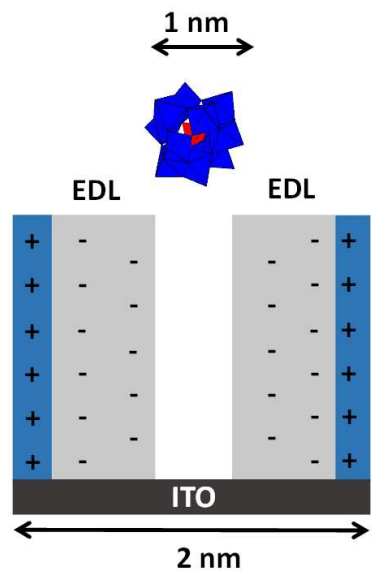

$0.1 \mathrm{M}<\mathrm{I}<0.4 \mathrm{M}$

EDLs close to overlapping

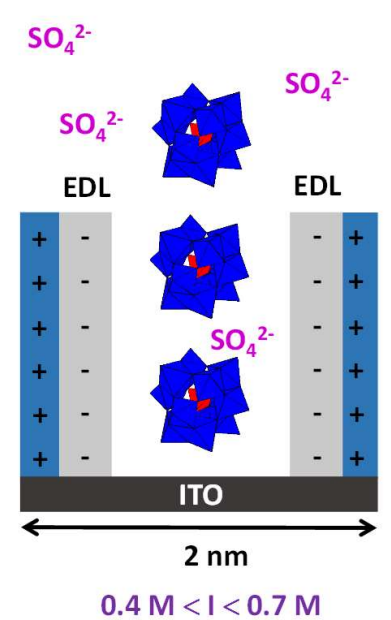

Optimal ionic strength favoring the accumulation of anionic redox probes

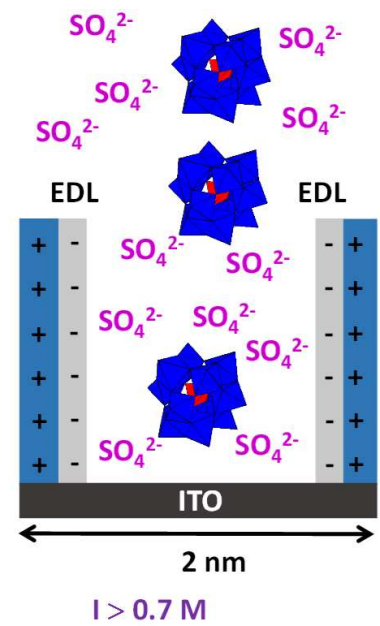

Competition between the anionic redox probes and $\mathrm{SO}_{4}{ }^{2-}$

Scheme 3. Schematic representation of the influence of ionic strength on the ingress of POM anions through positively charged nanochannels (acidic media) as a result of variations in EDL thickness, and competitive effects in concentrated sulfate solutions.

\section{ACKNOWLEDGEMENTS}

This work was supported partly by the french PIA project "Lorraine Université d'Excellence", reference ANR-15-IDEX-04-LUE. N.V. is gratefully acknowledged to CNRS for mobility funding (“CNRS delegation”). The authors thank the Université de Lorraine, the Université Paris-Sud and the CNRS for additional financial support. 


\section{References}

${ }^{1}$ S. H. Behrens, D. G. Grier, The charge of the glass and silica surfaces, J. Chem. Phys. 115, 2001, 6716.

${ }^{2}$ D. A. Sverjensky, N Sahai, Theoretical prediction of single-site surface protonation equilibrium constants for oxides and silicates in water, Geochim. Cosmochim. Acta 60 (1996) 3773.

${ }^{3}$ M. Etienne, A. Quach, D. Grosso, L. Nicole, C. Sanchez, A. Walcarius, Molecular transport into mesostructured silica thin films: electrochemical monitoring and comparison between $\mathrm{p} 6 \mathrm{~m}, \mathrm{P} 6_{3} / \mathrm{mmc}$ and $\mathrm{Pm} 3 \mathrm{n}$ structures, Chem. Mater. 19 (2007) 844.

${ }^{4}$ A. Walcarius, E. Sibottier, M. Etienne, J. Ghanbaja, Electrochemically assisted self-assembly of mesoporous silica thin films, Nature Mater. 6 (2007) 602.

${ }^{5}$ N. Vilà, E. André, R. Ciganda, J. Ruiz, D. Astruc, A. Walcarius, Molecular sieving with vertically aligned mesoporous silica films and electronic wiring through isolating nanochannels, Chem. Mater. 28 (2016) 2511.

${ }^{6}$ M. Etienne, A. Goux, E. Sibottier, A. Walcarius, Oriented mesoporous organosilica films on electrode : a new class of nanomaterials for sensing, J. Nanosci. Nanotechnol. 9 (2009) 2398.

${ }^{7}$ Y. Guillemin, M. Etienne, E. Aubert, A. Walcarius, Electrogeneration of highly methylated mesoporous silica thin films with vertically-aligned mesochannels and electrochemical monitoring of mass transport issues, J. Mater. Chem. 20 (2010) 6799.

${ }^{8}$ N. Vilà, J. Ghanbaja, E. Aubert, A. Walcarius, Electrochemically-assisted generation of highly ordered azidefunctionalized mesoporous silica for oriented hybrid films, Angew. Chem. Int. Ed. 53 (2014) 2945.

${ }^{9} \mathrm{~N}$. Vilà, J. Ghanbaja, A. Walcarius, Clickable bifunctional and vertically-aligned mesoporous silica films, Adv. Mater. Interfaces 3 (2016) 1500440.

10 J. Li, D. Stein, C. McMullan, D. Branton, M. J. Aziz, J. A. Golovchenko, lon-beam sculpting at nanometre length scales, Nature 412 (2001) 166.

${ }^{11}$ A. J. Storm; J. H. Chen; X. S. Ling, H. W. Zandbergen, C. Dekker, Fabrication of solid-state nanopores with singlenanometre precision, Nature Mater. 2 (2003) 537.

${ }^{12}$ C. Dekker, Solid-state nanopores. Nature Nanotechnol. 2 (2007) 209.

${ }^{13}$ S. Howorka; S. Cheley; H. Bayley, Sequence-specific detection of individual DNA strands using engineered nanopores, Nature Biotechnol. 19 (2001) 636.

${ }^{14} \mathrm{H}$. Craighead, Future lab-on-a-chip technologies for interrogating individual molecules, Nature 442 (2006) 387.

${ }^{15}$ S. Howorka; Z. Siwy, Nanopore analytics: sensing of single molecules, Chem. Soc. Rev. 38 (2009) 2360.

${ }^{16}$ C. Stein, M. Kruithof, C. Dekker, Surface-charge-governed ion transport in nanofluidic channels, Phys. Rev. Lett. 93 (2004) 035901.

${ }^{17} \mathrm{Q}$. Pu, J. Yun, H. Temkin, S. Liu, Ion-enrichment and ion-depletion effect of nanochannel structures, Nano Lett. 4 (2004) 1099.

18 J. Duan, A. Majumdar, Anomolous ion transport in 2-nm hydrophilic nanochannels, Nature Nanotechnol. 5 (2010) 848.

${ }^{19}$ M. Majumder, N. Chopra, R. Andrews, B. J. Hinds, Nanoscale hydrodynamics - Enhanced flow in carbon nanotubes, Nature 438 (2005) 44.

${ }^{20}$ R. K. Joshi, P. Carbone, F. Wang, V. G. Kravets, Y. Su, I. V. Grigorieva, H. Wu, A. K. Geim, R. R. Nair, Precise and ultrafast molecular sieving through graphene oxide membranes, Science 343 (2014) 752.

${ }^{21}$ M. Etienne, Y. Guillemin, D. Grosso, A. Walcarius, Electrochemical approaches for the fabrication and/or characterization of pure and hybrid templated mesoporous oxide thin films: a review, Anal. Bioanal. Chem. 405 (2013) 1497.

${ }^{22}$ M. Etienne, A. Walcarius, Evaporation induced self-assembly of templated silica and organosilica thin films on various electrode surfaces, Electrochem. Commun. 7 (2005) 1449.

${ }^{23}$ M. Etienne, S. Sallard, M. Schröder, Y. Guillemin, S. Mascotto, B. M. Smarsly, A. Walcarius, Electrochemical generation of thin silica films with hierarchical porosity, Chem. Mater. 22 (2010) 3426.

${ }^{24}$ M. T. Pope, A. Müller, Polyoxometalate chemistry: an old field with new dimensions in several disciplines, Angew. Chem. Int. Ed. 30 (1991) 34.

${ }^{25}$ M. Pope, Heteropoly and isopoly oxometalates, Springer-Verlag Berlin Heidelberg, 1983, p XIII, 180. 
${ }^{26}$ D.-L. Long, R. Tsunashima, L. Cronin, Polyoxometalates: building blocks for functional nanoscale systems, Angew. Chem. Int. Ed. 49 (2010) 1736.

${ }^{27}$ R. Contant, G. Herveb, The heteropolyoxotungstates: relationships between routes of formation and structures, Rev. Inorg. Chem. 22 (2002) 63.

${ }^{28}$ A. Müller, P. Kögerler, From simple building blocks to structures with increasing size and complexity, Coord. Chem. Rev. 182 (1999) 3.

${ }^{29}$ D.-L. Long, E. Burkholder, L. Cronin, Polyoxometalate clusters, nanostructures and materials: From self- assembly to designer materials and devices, Chem. Soc. Rev. 36 (2007) 105.

30 D. M. Fernandes, M. Nunes, R. J. Carvalho, R. Bacsa, I.-M. Mbomekalle, P. Serp, P. de Oliveira, C. Freire, Biomolecules electrochemical sensing properties of a PMo11V@N-doped few layer graphene nanocomposite, Inorganics 3 (2015) 178.

${ }^{31} \mathrm{~S}$. Herrmann, C. Ritchie, C. Streb, Polyoxometalate - conductive polymer composites for energy conversion, energy storage and nanostructured sensors, Dalton Trans. 44 (2015) 7092.

${ }^{32}$ N. Kawasaki, H. Wang, R. Nakanishi, S. Hamanaka, R. Kitaura, H. Shinohara, T. Yokoyama, H. Yoshikawa, K. Awaga, Nanohybridization of polyoxometalate clusters and single-wall carbon nanotubes: Applications in molecular cluster batteries. Angew. Chem. Int. Ed. 50 (2011) 3471.

$33 \mathrm{~J}$. Dou, H. C. Zeng, Targeted synthesis of silicomolybdic acid (Keggin acid) inside mesoporous silica hollow spheres for Friedel-Crafts alkylation, J. Am. Chem. Soc. 134 (2012) 16235.

${ }^{34}$ B. Keita, T. Liu, L. Nadjo, Synthesis of remarkably stabilized metal nanostructures using polyoxometalates, J. Mater. Chem. 19 (2009) 19.

35 B. Keita, I.-M. Mbomekalle, L. Nadjo, C. Haut, Tuning the formal potentials of new VIV-substituted Dawson-type polyoxometalates for facile synthesis of metal nanoparticles, Electrochem. Commun. 6 (2004) 978.

${ }^{36}$ J. F. Keggin, Structure of the molecule of 12-Phosphotungstic Acid, Nature 131 (1933) 908.

${ }^{37}$ M. T. Pope, G. M. Varga, Heteropoly Blues. I. Reduction stoichiometries and reduction potentials of some 12Tungstates, Inorg. Chem. 5 (1966) 1249.

${ }^{38}$ I.-M. Mbomekallé, X. López, J. M. Poblet, F. Sécheresse, B. Keita, L. Nadjo, Influence of the heteroatom size on the redox potentials of selected polyoxoanions, Inorg. Chem. 49 (2010) 7001.

${ }^{39}$ B. Keita, L. Nadjo, New aspects of the electrochemistry of heteropolyacids. Part II. Coupled electron and proton transfers in the reduction of silicotungstic species, J. Electroanal. Chem. Interfacial Electrochem. 217 (1987) 287.

${ }^{40} \mathrm{C}$. Karman, N. Vilà, A. Walcarius, Amplified charge transfer for anionic redox probes through oriented mesoporous silica thin films, ChemElectroChem 12 (2016) 2130.

${ }^{41}$ A. Téazéa, G. Hervéa, R. G. Finke, D. K. Lyon, $\alpha-, \beta$-, and $\gamma$-dodecatungstosilicic acids: isomers and related lacunary compounds. Inorg. Synth. 1990, vol.27, 93-94.

${ }^{42}$ A. Goux, M. Etienne, E. Aubert, C. Lecomte, J. Ghanbaja, A. Walcarius, Oriented mesoporous silica films obtained by electro-assisted self-assemby (EASA), Chem. Mater. 21 (2009) 731.

${ }^{43}$ T. Nasir, G. Herzog, M. Hébrant, C. Despas, A. Walcarius, Mesoporous silica thin films for improved electrochemical detection of paraquat, ACS Sensors 3 (2018) 484.

${ }^{44}$ Z. Stojek, in Electroanalytical Methods (Ed.: F. Scholz), Springer, Berlin Heidelberg, Germany, 2010, pp. 3 - 9.

${ }^{45}$ X. Lin, Q. Yang, F. Yan, B. Zhang, B. Su, Gated molecular transport in highly ordered heterogeneous nanochannel array electrode, ACS Appl. Mater. Interfaces 8 (2016) 33343. 